\title{
KINESIOGRAPHIC STUDY OF MANDIBULAR MOVEMENTS DURING FUNCTIONAL ADAPTATION TO COMPLETE DENTURES
}

\author{
ESTUDO CINESIOGRÁFICO DOS MOVIMENTOS MANDIBULARES DURANTE \\ O PERÍODO DE ADAPTAÇÃO FUNCIONAL A PRÓTESES TOTAIS
}

\author{
Cláudio Rodrigues LELES \\ Professor, Department of Prevention and Oral Rehabilitation, School of Dentistry, Federal University of Goiás, Goiânia, Goiás, Brazil.

\section{Marco Antonio COMPAGNONI} \\ Professor, Department of Dental Materials and Prosthodontics, Araraquara Dental School, São Paulo State University, Araraquara, São \\ Paulo, Brazil. \\ Raphael Freitas de SOUZA \\ Graduate student, Department of Dental Materials and Prosthodontics, Araraquara Dental School, São Paulo State University, Araraquara, \\ São Paulo, Brazil.

\section{Débora Barros BARBOSA} \\ Graduate student, Department of Dental Materials and Prosthodontics, Araraquara Dental School, São Paulo State University, Araraquara, \\ São Paulo, Brazil.
}

\begin{abstract}
A fter complete denture insertion, edentulous patients usually present transitory difficulties. This is one of the most critical stages of prosthetic treatment and it is strongly related to the prostheses acceptance. The aim of this study was to evaluate potential changes in the mandibular movement pattern related to insertion of the complete denture during the functional adaptation period. The kinesiograph instrument K6-I (Myotronics Research Inc., Seattle, WA) was used to evaluate eight edentulous patients that received conventional complete denture treatment. Recordings of opening and closure movement limits, movement velocity, postural rest position, chewing cycle and limits of eccentric movements were performed. Each patient was evaluated in four different stages: with the old dentures, immediately after insertion of the new dentures, and 30 days and 6 months after insertion of the dentures. The results showed that there were no remarkable changes in the mandibular motion patterns after insertion of the new dentures. It was suggested that the problems related to the process of utilization of new dentures are not strictly associated to the mandibular movement. Therefore, functional adaptation after denture insertion is not directly related to functional changes, but to the quality of the dentures and to individual features.
\end{abstract}

UNITERMS: Complete denture; Patients; Kinesiography.

\section{INTRODUCTION}

Denture insertion is the summit of all clinical procedures of denture construction and is eagerly awaited by both patient and clinician ${ }^{20}$. However, after denture insertion, a set of adaptive difficulties can emerge. Transitory problems like masticatory impairment, mandibular incoordination, excessive salivary flow and phonetic troubles are common, even if the denture is well planned and constructed ${ }^{1}$. Pain related to the denture-bearing tissues and faults in denture retention or stability are frequently observed, mainly due to occlusal imbalance, incorrect vertical dimension and occlusion, or improper contour of the denture base ${ }^{8}$. These factors may reduce the patient's comfort and satisfaction and influence the wearing of complete dentures on a daily basis $^{4,19}$.

Fish $^{5}$ observed that these initial difficulties are caused by alterations in the tongue position relative to the oral mucosa, restriction of the space available for the tongue, load transmitted to the supporting tissues, changes in muscle proprioceptive impulses, and alteration of vertical facial height and mandibular rest position.

After this transitory period, the patients acquire a neuromuscular control that compensates eventual deficiencies of the prostheses and maintain long-term functional balance and comfort ${ }^{16}$. 
Several factors that influence this adaptation period were studied in the natural dentition, such as the vertical dimension ${ }^{3,6,13,14,22}$, oral sensory threshold ${ }^{12}$ and occlusal status $^{30}$. Research methods include clinical evaluation, electromyography and kinesiography.

The study of mandibular movement dynamics is not new, but only in the 70's Jankelson, et al. ${ }^{7}$ introduced the kinesiograph as an instrument for diagnosis and clinical research in dentistry. This instrument was largely used for monitoring dentate individuals, although few studies were conducted for complete denture patients. Tallgren, et al. ${ }^{27,28}$ observed that patients without posterior dental support perform irregular movements and the insertion of immediate maxillary dentures opposed to mandibular removable partial dentures restored functional occlusion state and significantly improved the mandibular movement pattern. Additionally, a two-year longitudinal study showed that the range of movement is considerably reduced, probably due to the progressive loss of retention of the dentures ${ }^{28}$. Other kinesiographic studies highlight the importance of the quality of the denture for restoration and maintenance of the chewing pattern and cyclic mandibular movements ${ }^{9,10,25}$.

The aim of the current study was to evaluate, by means of a kinesiographic instrument, the functional changes of mandibular movement parameters associated to insertion of new dentures, during different stages of adjustment of the patients to complete dentures.

\section{MATERIAL AND METHODS}

Completely edentulous patients who attended the Araraquara Dental School and were treated with complete dentures were randomly selected. Inclusion criteria included patients who needed new dentures, mentally receptive individuals, absence of dysfunctional disorders of the masticatory system, normal volume and resilience of the residual edentulous ridges, and absence of debilitating systemic diseases.

Patients were selected to receive upper and lower conventional complete dentures constructed according to a standardized protocol as described by Russi, et al. ${ }^{23}$ The Ethics Committee of the school has approved the research project and an informed consent term was obtained from the patients before any experimental procedure.

Eight patients met the criteria and were selected for the study. Six were female and two were male, age ranging from 37 to 77 years (mean age: 61 years). The mean time of denture usage was 29 years.

After completion of clinical treatment, during the insertion visit, the quality of retention and stability, comfort and esthetics were tested. Points of occlusion were selectively ground and possible pressure spots were disclosed with a pressure indicator paste and relieved. After clinical adjustments, kinesiographic analysis was performed in the same appointment.

A kinesiographic instrument (K6-I Diagnostic SystemMyotronics Research Inc., Seattle, WA, USA) connected to a computerized system was used to graphically record the mandibular movements. This system has a sensor array (Figure 1) and a 12x6x3mm magnet tracking device (Figure 2) that records the spatial three-dimensional position of the mandible during functional movements.

Kinesiographic analysis was divided into three different periods of time: (1) immediate, (2) short-term and (3) longterm. Immediate period was evaluated with old and new dentures.

1. Immediate: during the denture insertion visit and after the intraoral adjustments. Assessment of transition between new and old dentures was recorded in the same visit. Measurement series were coded as STAGE I (old dentures), and STAGE II (new dentures). Stage I was considered the

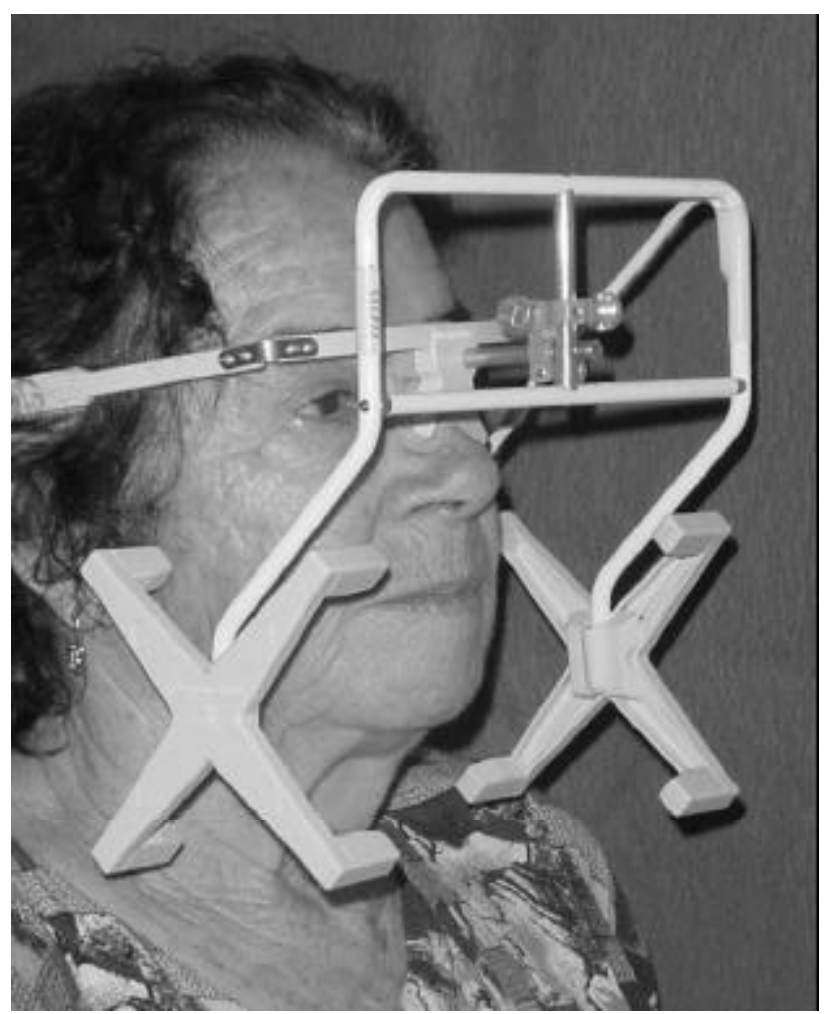

FIGURE 1- Sensor array in position

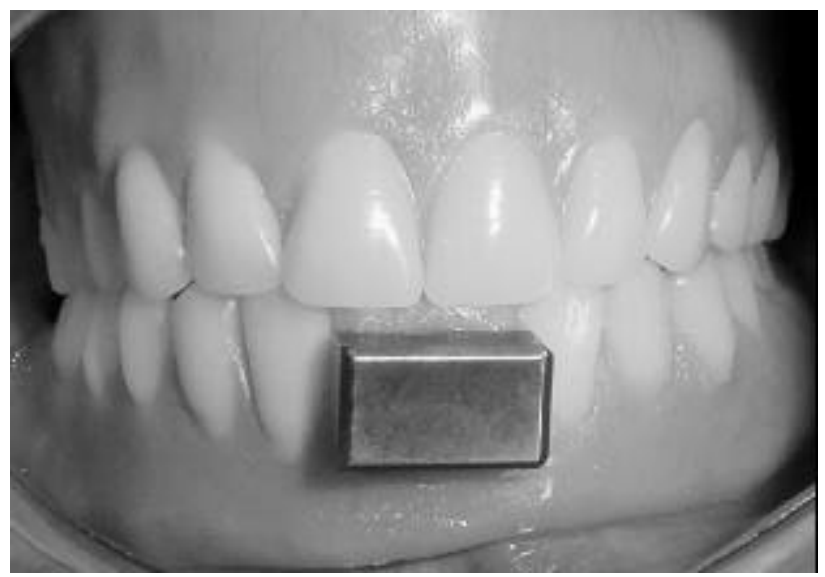

FIGURE 2- Magnet tracking device attached to the midline labial surface of the mandibular denture 
pre-insertion pattern of mandibular movement.

2. Short-term (STAGE III): to avoid confounding factors, like sore points that might occur during the postinsertion period, recordings were made after the last followup visit, when complete adaptation to the dentures had been achieved. The estimated maximum time interval for this stage was 30 days after insertion of the denture.

3. Long-term (STAGE IV): about six months after insertion of the dentures.

The mean time interval elapsed between stage II (denture insertion) and stage III was 30 days (range: 18 - 32 days), and between stage II and IV was 170 days (range: 156 231 days).

Five tracing modes (scan) were selected for recordings. Description of mandibular movements and respective tracing modes are summarized in Table 1.

Recordings were performed according to the manufacturer's instructions and three reproducible measurements were recorded for each scan mode.

Descriptive statistics were performed and comparative analysis was made using the non-parametric Wilcoxon signed ranks test, at a confidence level of 5\%. Data analysis was done with the Statistical Package for the Social Sciences software (SPSS 10.0 for Windows, SPSS Inc., 1999).

\section{RESULTS}

The results of recordings are listed in Table 2-11, according to scan tracings.

\section{DISCUSSION}

Satisfactory function and comfort are related to a balanced occlusion, correct vertical dimension and proper base extension ${ }^{4}$. Regardless of general health condition and psychological traits, the quality of the dentures and other local favorable aspects are good predictors of treatment success ${ }^{2}$. Nevertheless, functional adaptation to dentures has multidimensional aspects and consequences that influence the patient's satisfaction. Patients must be aware that, after insertion of the dentures, a new muscular behavior may develop in order to control the functional activities ${ }^{12,15,16}$. Nearly $60 \%$ of denture wearers achieve satisfactory function within a week after insertion and about $20 \%$ within one month ${ }^{1}$.

Functional parameters to be considered after dentures' insertion include patients' subjective appraisal of dentures ${ }^{15,16}$, chewing efficiency ${ }^{16,29}$, masticatory frequency and muscular coordination ${ }^{15,16}$, chewing cycle consistency ${ }^{15}$, and occlusal perception ${ }^{11}$. Previous studies suggest that all these parameters significantly improve after the postinsertion period because a compensatory neuromuscular

TABLE 1- Preprogrammed scan numbers corresponding to scan tracings

\begin{tabular}{ll}
\hline Scan & \multicolumn{1}{c}{ Description } \\
\hline 1 & Normal opening and closure of mandibular movement \\
2 & Speed of the mandible during opening and closure \\
3 & Three-dimensional movement of the mandible from rest position to maximal occlusion \\
8 & Three-dimensional movements of the mandible during chewing. Test food - a cube of 15x10x10mm cured polysulfide \\
13 & (Permlastic Regular - Kerr Corporation, USA) \\
\hline
\end{tabular}

TABLE 2- Mean opening mandibular movement recorded in the sagittal plane (in millimeters)

\begin{tabular}{|c|c|c|c|c|}
\hline Patient & Stage I & Stage II & Stage III & Stage IV \\
\hline 1 & 56.7 & 57.8 & 56.9 & 57.3 \\
\hline 2 & 56.8 & 60.3 & 59.5 & 57.8 \\
\hline 3 & 41.4 & 35.8 & 45.6 & 42.1 \\
\hline 4 & 27.6 & 27.2 & 35.5 & 42.6 \\
\hline 5 & 66.0 & 50.6 & 55.6 & 54.1 \\
\hline 6 & 41.2 & 47.5 & 49.3 & 47.7 \\
\hline 7 & 47.0 & 38.2 & 48.4 & 45.9 \\
\hline 8 & 54.2 & 54.9 & 54.2 & 59.2 \\
\hline
\end{tabular}


modification is developed by the patients ${ }^{11,15,16,16,29}$. However, these factors are not related to the mandibular coordination or extension of mandibular range of movement. It is better explained by the patients' ability to cope with difficulties, learning capability and continuous reinforcement of functional activities ${ }^{17}$.

Periodontal and temporomandibular joint receptors play an important role in controlling occlusal forces and mandibular movements, respectively ${ }^{17}$. Even if periodontal proprioception is absent, as in the edentulous patient, the

TABLE 3- Mean deviation from midline during opening mandibular movement in the frontal plane (in millimeters)

\begin{tabular}{lllllllll}
\hline Patient & \multicolumn{2}{c}{ Stage I } & \multicolumn{2}{c}{ Stage II } & \multicolumn{2}{c}{ Stage III } & \multicolumn{2}{c}{ Stage IV } \\
& Right & Left & Right & Left & Right & Left & Right & Left \\
\hline 1 & 0.3 & 14.2 & 0.5 & 14.0 & 0.1 & 13.7 & 0.5 & 7.8 \\
2 & 0.2 & 13.7 & 2.4 & 12.7 & 1.5 & 6.1 & 1.4 & 6.0 \\
3 & 2.9 & 4.6 & 4.2 & 2.3 & 1.4 & 5.7 & 1.6 & 4.3 \\
4 & 0.4 & 6.5 & 0.1 & 7.0 & 0.1 & 9.7 & 0.4 & 3.1 \\
5 & 0.2 & 10.4 & 1.7 & 10.8 & 1.4 & 9.0 & 2.1 & 6.2 \\
6 & 0.9 & 9.7 & 0.5 & 16.1 & 0.6 & 12.7 & 1.1 & 3.3 \\
7 & 0.3 & 8.3 & 0.6 & 4.3 & 0.9 & 8.9 & 0.8 & 3.7 \\
8 & 0.2 & 9.8 & 1.4 & 11.1 & 2.1 & 3.5 & 1.9 & 2.7 \\
\hline
\end{tabular}

TABLE 4- Maximum and mean mandibular speed during opening movement (in millimeters per second)

\begin{tabular}{lllllllll}
\hline Patient & \multicolumn{2}{c}{ Stage I } & \multicolumn{2}{c}{ Stage II } & \multicolumn{2}{c}{ Stage III } & \multicolumn{2}{c}{ Stage IV } \\
& Max. & Mean & Max. & Mean & Max. & Mean & Max. & Mean \\
\hline 1 & 177.1 & 91.6 & 152.5 & 76.3 & 134.6 & 75.9 & 143.8 & 84.2 \\
2 & 191.6 & 107.2 & 260.8 & 151.1 & 276.7 & 159.1 & 188.0 & 182.9 \\
3 & 120.4 & 60.7 & 129.6 & 76.2 & 86.3 & 48.8 & 135.9 & 65.7 \\
4 & 103.8 & 60.7 & 83.8 & 53.3 & 127.5 & 74.6 & 208.4 & 120.4 \\
5 & 140.0 & 79.9 & 117.5 & 77.9 & 120.4 & 76.1 & 112.5 & 69.2 \\
6 & 230.5 & 138.1 & 180.9 & 108.8 & 137.5 & 80.3 & 131.3 & 71.7 \\
7 & 65.5 & 36.5 & 82.5 & 43.8 & 75.4 & 54.5 & 113.4 & 70.0 \\
8 & 133.8 & 88.0 & 161.4 & 77.4 & 150.1 & 72.8 & 210.0 & 185.0 \\
\hline
\end{tabular}

TABLE 5- Maximum and mean mandibular speed during closure movement (in millimeters per second)

\begin{tabular}{lllllllll}
\hline Patient & \multicolumn{2}{c}{ Stage I } & \multicolumn{2}{c}{ Stage II } & \multicolumn{2}{c}{ Stage III } & \multicolumn{2}{c}{ Stage IV } \\
& Max. & Mean & Max. & Mean & Max. & Mean & Max. & Mean \\
\hline 1 & 145.4 & 70.5 & 90.4 & 53.6 & 117.1 & 51.6 & 108.3 & 52.4 \\
2 & 141.1 & 74.2 & 250.5 & 136.1 & 219.2 & 123.8 & 200.5 & 109.4 \\
3 & 120.0 & 67.5 & 122.1 & 76.1 & 107.9 & 62.4 & 132.5 & 75.1 \\
4 & 95.5 & 53.5 & 69.2 & 34.7 & 78.8 & 41.5 & 95.7 & 51.0 \\
5 & 168.4 & 102.8 & 139.6 & 72.8 & 132.1 & 79.9 & 127.1 & 73.7 \\
6 & 104.2 & 61.8 & 113.4 & 66.0 & 91.7 & 59.3 & 66.7 & 42.8 \\
7 & 81.7 & 40.2 & 65.0 & 36.6 & 83.8 & 36.0 & 66.3 & 33.4 \\
8 & 76.3 & 45.3 & 66.2 & 39.3 & 59.5 & 31.9 & 288.3 & 156.0 \\
\hline
\end{tabular}


masticatory dynamics remains unaltered because chewing is controlled by a central neural generator that modulates rhythmic activities ${ }^{17,24}$.

The present study reveals that the insertion of dentures does not alter the pattern, speed and limits of nonfunctional movements. In contrast, Tallgren et al. ${ }^{28}$ observed improvement in mastication and range of movement after insertion of maxillary immediate denture and mandibular extension-base removable partial denture. This improvement can be affected by the retention of the dentures ${ }^{28}$.

Another factor that influences adaptation to new dentures is the change in occlusion. Investigations in dentate individuals show that modifications in occlusal guidance significantly alter lateral border movements ${ }^{21}$. Nevertheless,

TABLE 6- Speed of terminal contact during closure movement of mandible (in millimeters per second)

\begin{tabular}{lllll}
\hline Patient & Stage I & Stage II & Stage III & Stage IV \\
\hline 1 & 17.9 & 9.2 & 8.8 & 7.1 \\
2 & 13.9 & 15.8 & 25.9 & 26.4 \\
3 & 7.9 & 14.2 & 10.4 & 20.4 \\
4 & 12.1 & 12.9 & 3.0 & 4.2 \\
5 & 12.9 & 14.2 & 18.8 & 15.4 \\
6 & 20.8 & 21.3 & 15.9 & 8.8 \\
7 & 14.0 & 12.9 & 8.4 & 5.4 \\
8 & 4.2 & 1.9 & 6.7 & 7.9 \\
\hline
\end{tabular}

TABLE 7- Mean vertical (V), anteroposterior (AP) and lateral (L) movement between rest position and intercuspal position (in millimeters)

\begin{tabular}{lcccccccccccc}
\hline Patient & \multicolumn{3}{c}{ Stage I } & \multicolumn{3}{c}{ Stage II } & \multicolumn{3}{c}{ Stage III } & \multicolumn{3}{c}{ Stage IV } \\
& V & A-P & L & V & A-P & L & V & A-P & L & V & A-P & L \\
\hline 1 & 6.0 & 2.5 & 0.3 & 2.0 & 0.9 & 0.1 & 0.8 & 0.9 & 0.4 & 1.5 & 1.3 & 0.1 \\
2 & 2.9 & 1.9 & 0.4 & 3.2 & 1.9 & 0.6 & 3.6 & 2.1 & 0.6 & 3.6 & 2.1 & 0.6 \\
3 & 1.4 & 0.5 & 0.1 & 1.3 & 0.7 & 0.1 & 1.4 & 0.2 & 0.2 & 2.3 & 0.9 & 0.4 \\
4 & 5.1 & 5.1 & 1.3 & 2.8 & 2.1 & 0.6 & 3.7 & 2.4 & 0.8 & 3.9 & 2.8 & 0.3 \\
5 & 12.1 & 5.7 & 0.4 & 3.3 & 2.5 & 0.3 & 2.2 & 1.6 & 0.1 & 2.7 & 0.5 & 0.2 \\
6 & 7.1 & 3.9 & 0.8 & 3.1 & 3.1 & 0.2 & 2.0 & 1.4 & 0.1 & 1.9 & 1.9 & 0.4 \\
7 & 7.5 & 4.8 & 1.5 & 2.9 & 2.4 & 0.3 & 2.6 & 1.7 & 0.3 & 3.6 & 2.4 & 0.2 \\
8 & 3.6 & 3.0 & 0.8 & 2.2 & 0.8 & 0.3 & 1.4 & 1.3 & 0.8 & 5.0 & 4.1 & 0.9 \\
\hline
\end{tabular}

TABLE 8- Mean vertical mandibular movement during chewing (in millimeters)

\begin{tabular}{cllll}
\hline Patient & Stage I & Stage II & Stage III & Stage IV \\
\hline 1 & 7.2 & 9.2 & 6.2 & 8.8 \\
2 & 11.0 & 9.2 & 13.5 & 13.4 \\
3 & 6.0 & 4.8 & 6.3 & 13.1 \\
4 & 11.0 & 12.6 & 9.9 & 11.4 \\
5 & 14.2 & 10.4 & 8.6 & 11.3 \\
6 & 7.5 & 11.0 & 9.0 & 6.7 \\
7 & 8.7 & 7.2 & 6.9 & 7.0 \\
8 & 9.9 & 10.6 & 7.1 & 8.3 \\
\hline
\end{tabular}


it is not possible to reach any conclusion on the clinical significance of these changes if complaints are not detected and overall comfort, esthetic satisfaction and functional improvement are achieved.

The most significant modifications are related to the vertical dimension. The consequences are variations in muscular activity, rest position of the mandible and consequently in the interocclusal distance, observed in dentate ${ }^{6,13,14}$ and edentulous patients. ${ }^{18,26}$ However, it is well recognized that minor or gradual moderate changes in vertical dimension do not cause deleterious problems if a stable and well distributed occlusion is achieved ${ }^{3}$.

It can be suggested that adaptation to new dentures is not closely related to functional changes. Intrinsic denture problems and individual subjective problems related to the patient may play a major role during the post-insertion process. Consequently, a careful appraisal of clinical and psychological conditions and a realistic outcome of the treatment are important aspects of patient management. A comprehensive treatment planning is essential for a satisfactory post-insertion period and long-term success of treatment.

\section{CONCLUSION}

Within the limitations of this study, it was concluded that the pattern of mandibular movement does not demonstrate significant changes between the pre and postinsertion stages of utilization of complete dentures. Functional transitory problems after insertion of the denture may not be associated to changes in the coordination of the mandibular movement.

\section{ACKNOWLEDGMENTS}

This research was supported by The State of Sao Paulo Research Foundation (Fapesp - Grant no. 99/06609-8).

\section{RESUMO}

Após a instalação de próteses totais, o paciente desdentado geralmente enfrenta dificuldades transitórias. Esse estágio é um dos mais críticos durante o tratamento protético desses pacientes, estando relacionado à aceitação das próteses. $\mathrm{O}$ presente estudo teve como objetivo avaliar as possíveis

TABLE 9- Mean range of anterior (protrusive) and lateral movements (in millimeters)

\begin{tabular}{|c|c|c|c|c|c|c|c|c|c|c|c|c|}
\hline \multirow[t]{2}{*}{ Patient } & \multicolumn{3}{|c|}{ Stage I } & \multicolumn{3}{|c|}{ Stage II } & \multicolumn{3}{|c|}{ Stage III } & \multicolumn{3}{|c|}{ Stage IV } \\
\hline & Ant. & Right & Left & Ant. & Right & Left & Ant. & Right & Left & Ant. & Right & Left \\
\hline 1 & 8.1 & 9.8 & 6.6 & 6.7 & 7.3 & 8.3 & 4.4 & 10.5 & 8.8 & 7.2 & 10.2 & 9.7 \\
\hline 2 & 3.5 & 10.6 & 10.2 & 2.9 & 13.8 & 6.9 & 2.6 & 12.1 & 9.5 & 2.0 & 12.4 & 9.7 \\
\hline 3 & 2.9 & 3.4 & 2.2 & 2.0 & 6.7 & 1.7 & 7.0 & 4.8 & 2.4 & 10.0 & 8.8 & 7.7 \\
\hline 4 & 3.2 & 4.7 & 5.9 & 6.7 & 4.1 & 9.1 & 7.1 & 1.0 & 8.4 & 7.1 & 5.8 & 7.5 \\
\hline 5 & 4.8 & 7.9 & 4.0 & 9.8 & 10.3 & 4.3 & 11.5 & 9.7 & 5.8 & 9.4 & 11.5 & 4.7 \\
\hline 6 & 5.9 & 5.8 & 1.2 & 5.0 & 5.6 & 0.4 & 6.8 & 5.0 & 2.3 & 5.4 & 5.9 & 4.9 \\
\hline 7 & 6.5 & 5.6 & 7.2 & 7.3 & 8.9 & 6.7 & 1.8 & 9.9 & 4.4 & 7.9 & 10.3 & 8.2 \\
\hline 8 & 4.3 & 5.5 & 5.8 & 4.1 & 5.8 & 4.3 & 9.1 & 8.0 & 7.6 & 7.0 & 7.1 & 8.1 \\
\hline
\end{tabular}

TABLE 10- Mean distance (range of movement) between intercuspal position and maximum opening (in millimeters)

\begin{tabular}{|c|c|c|c|c|}
\hline Patient & Stage I & Stage II & Stage III & Stage IV \\
\hline 1 & 51.2 & 54.7 & 49.9 & 47.0 \\
\hline 2 & 55.7 & 62.2 & 57.3 & 59.7 \\
\hline 3 & 37.4 & 38.6 & 40.0 & 45.0 \\
\hline 4 & 35.3 & 28.3 & 36.8 & 43.1 \\
\hline 5 & 62.8 & 54.4 & 56.1 & 49.8 \\
\hline 6 & 55.3 & 48.5 & 49.7 & 41.4 \\
\hline 7 & 41.1 & 38.8 & 40.6 & 42.8 \\
\hline 8 & 47.3 & 49.9 & 50.5 & 41.8 \\
\hline
\end{tabular}


alterações no padrão de movimentos mandibulares decorrentes da instalação de próteses totais em indivíduos desdentados, durante o período de adaptação funcional. $\mathrm{O}$ sistema de diagnóstico cinesiográfico K6-I (Myotronics Research Inc., Seattle, WA) foi empregado para avaliação de 08 pacientes que foram previamente tratados para confecção de próteses totais. Foram realizados registros da amplitude do movimento mandibular de abertura e fechamento, velocidade do movimento mandibular durante a abertura e fechamento, movimento da mandíbula entre a posição de repouso postural e a máxima intercuspidação, movimento da mandíbula durante a mastigação e registro do limite de movimento mandibular de abertura e fechamento, lateralidade e protrusão. Os pacientes foram avaliados com as próteses antigas, no período imediato à instalação das próteses e nos períodos de aproximadamente 30 dias e 6 meses pós-instalação. Os resultados demonstraram que o padrão dos movimentos mandibulares pouco se altera entre os períodos pré e pós-instalação e entre diferentes estágios após a instalação das próteses totais, o que sugere que as dificuldades funcionais após a instalação de próteses totais não estão relacionadas a alterações no padrão de coordenação dos movimentos mandibulares. Assim, a adaptação dos pacientes após a instalação de próteses totais não se relaciona propriamente a alterações funcionais do paciente, mas a características intrínsecas das próteses e a aspectos subjetivos individuais.

UNITERMOS: Dentadura completa; Pacientes; Cinesiografia.

\section{REFERENCES}

1- Berg E. Acceptance of full dentures. Int Dent J 1993; 43: 299306.

2- Brunello D, Mandikos M. Construction faults, age, gender, and relative medical health: factors associated with complaints in complete denture patients. J Prosthet Dent 1998; 79: 545-54.

3- Carlsson G, Ingervall B, Kocak G. Effect of increasing vertical dimension on the masticatory system in subjects with natural teeth. J Prosthet Dent 1979; 41: 284-9.

4- Fenlon M, Sherriff M, Walter J. Association between the accuracy of intermaxillary relations and complete denture usage. J Prosthet Dent 1999; 81: 520-5.

5- Fish S. Adaptation and habituation to full dentures. Br Dent $\mathrm{J}$ 1969; 127: 19-26.

6- Garnick J, Ramfjord S. Rest position. An electromyographic and clinical investigation. J Prosthet Dent 1962; 12: 895-911.

7- Jankelson B, Swain C, Crane P, Radke J. Kinesiometric instrumentation: a new technology. J Am Dent Assoc 1975; 90: 834-40.

8- Jeganathan S, Payne J. Common faults in complete dentures: a review. Quintessence Int 1993; 24: 483-7.

TABLE 11- Result of measurement contrasts

Recordings

Range of opening movement

Right deviation during opening movement

Left deviation during opening movement

Maximum speed during opening movement

Mean speed during opening movement

Maximum speed during closure movement

Mean speed during closure movement

Speed of terminal tooth contact

Vertical interocclusal space in rest position

Anteroposterior movement between rest position and intercuspal position

Lateral movement between rest position and intercuspal position

Vertical movement during chewing

Anterior movement limit

Right lateral movement limit

Left lateral movement limit

Range of movement between intercuspal position and maximum opening

*Statistically significant difference $(p<0.05)$ 
9- Jemt T, Hedegård B, Wickberg K. Chewing patterns before and after treatment with complete maxillary and bilateral distalextension mandibular removable partial dentures. J Prosthet Dent 1983; 50: 566-70.

10- Jemt T, Stålblad P. The effect of chewing movements on changing mandibular complete dentures to osseointegrated overdentures. J Prosthet Dent 1986; 55: 357-61.

11- Langer A, Michman J. Occlusal perception after placement of complete dentures. J Prosthet Dent 1968; 19: 246-51.

12- Manly R, Pfaffman C, Lathrop D, Keyser J. Oral sensory thresholds of persons with natural and artificial dentitions. J Dent Res 1952; 31: 305-12.

13- Manns A, Miralles R, Guerrero F. The changes in electrical activity of the postural muscles of the mandible upon varying the vertical dimension. J Prosthet Dent 1981; 45: 438-45.

14- Michelotti A, Farella M, Vollaro S, Martina R. Mandibular rest position and electrical activity of the masticatory muscles. J Prosthet Dent 1997; 78: 48-53.

15- Michman J, Langer A. Clinical and electromyographic observations during adjustment to complete dentures. J Prosthet Dent 1968; 19: 252-62.

16- Michman J, Langer A. Postinsertion changes in complete dentures. J Prosthet Dent 1975; 34: 125-34.

17- Mohl N. Neuromuscular mechanisms in mandibular function. Dent Clin North Am 1978; 22: 63-71.

18- Morimoto T, Abekura H, Tokuyama H, Hamada T. Alteration in the bite force and EMG activity with changes in the vertical dimension of edentulous subjects. J Oral Rehabil 1996; 23: 33641.

19- Morstad A, Petersen A. Postinsertion denture problems. J Prosthet Dent 1968; 19: 126-32.

20- Nagle R. Postinsertion problems in complete denture prosthesis. J Am Dent Assoc 1958; 57: 183-7.

21- Nishigawa K, Nakano M, Bando E, Clark G. Effect of altered occlusal guidance on lateral border movement of the mandible. $J$ Prosthet Dent 1992; 68: 965-9.

22- Rugh J, Drago C. Vertical dimension: a study of clinical rest position and jaw muscle activity. J Prosthet Dent 1981; 45: 67075.

23- Russi S, Lombardo G, Compagnoni M, Nogueira S. Prótese Total. Manual de Laboratório (Teoria e Prática). Araraquara: Faculdade de Odontologia; 1982.

24- Schindler H, Stengel E, Spiess W. Feedback control during mastication of solid food textures - a clinical-experimental study. J Prosthet Dent 1998; 80: 330-6.

25- Shi C, Ouyang G, Guo T. A comparative study of mastication between complete denture wearers and dentate subjects. J Prosthet Dent 1991; 66: 505-9.
26- Tallgren A, Holden S, Lang B, Ash Jr M. Jaw muscle activity in complete denture wearers - a longitudinal electromyographic study. J Prosthet Dent 1980; 44: 123-32.

27- Tallgren A, Tryde G, Mizutani H. Changes in jaw relations and activity of masticatory muscles in patients with immediate complete upper dentures. J Oral Rehabil 1986; 13: 311-24.

28- Tallgren A, Mizutani H, Tryde G. A two-year kinesiographic study of mandibular movement patterns in denture wearers. J Prosthet Dent 1989; 62: 594-600.

29- Vinton P, Manly R. Masticatory efficiency during the period of adjustment to dentures. J Prosthet Dent 1955; 5: 477-80.

30- Wood W, Gelfant H, Hannam A. Effect of occlusal reconstruction on the reproducibility of chewing movements. J Prosthet Dent 1981; 46: 181-4.

Recebido para publicação em: 26/02/2003

Enviado para reformulações em: 26/06/2003

Pronto para publicação em: 28/07/2003

Adress:

Cláudio R. Leles

Faculdade de Odontologia da UFG, Departamento de Prevenção e Reabilitação Oral

Praça Universitária, s/n, Setor Universitário

CEP 74.605-220 Goiânia-GO

e-mail: crleles@odonto.ufg.br 